


\section{HARNESSING TECHNOLOGY FOR MORE INCLUSIVE AND SUSTAINABLE FINANCE IN ASIA AND THE PACIFIC}

OCTOBER 2018 
(C) 2018 Asian Development Bank

6 ADB Avenue, Mandaluyong City, 1550 Metro Manila, Philippines

Tel +632632 4444; Fax +6326362444

www.adb.org

Some rights reserved. Published in 2018.

ISBN 978-92-9261-348-8 (print), 978-92-9261-349-5 (electronic)

Publication Stock No. TCS189581-2

DOI: http://dx.doi.org/10.22617/TCS189581-2

The views expressed in this publication are those of the authors and do not necessarily reflect the views and policies of the Asian Development Bank (ADB) or its Board of Governors or the governments they represent.

ADB does not guarantee the accuracy of the data included in this publication and accepts no responsibility for any consequence of their use. The mention of specific companies or products of manufacturers does not imply that they are endorsed or recommended by ADB in preference to others of a similar nature that are not mentioned.

By making any designation of or reference to a particular territory or geographic area, or by using the term "country" in this document, $A D B$ does not intend to make any judgments as to the legal or other status of any territory or area.

This work is available under the Creative Commons Attribution 3.0 IGO license (CC BY 3.0 IGO)

https://creativecommons.org/licenses/by/3.0/igo/. By using the content of this publication, you agree to be bound by the terms of this license. For attribution, translations, adaptations, and permissions, please read the provisions and terms of use at https://www.adb.org/terms-use\#openaccess.

This CC license does not apply to non-ADB copyright materials in this publication. If the material is attributed to another source, please contact the copyright owner or publisher of that source for permission to reproduce it. $\mathrm{ADB}$ cannot be held liable for any claims that arise as a result of your use of the material.

Please contact pubsmarketing@adb.org if you have questions or comments with respect to content, or if you wish to obtain copyright permission for your intended use that does not fall within these terms, or for permission to use the ADB logo.

Notes:

In this publication, “\$” refers to United States dollars.

ADB recognizes "China" as the People's Republic of China, "Korea" as the Republic of Korea, and

"Vietnam" as Viet Nam.

Corrigenda to ADB publications may be found at http://www.adb.org/publications/corrigenda. 


\section{Tables, Figures, and Boxes}

\section{TABLES}

1 Number of Fintech Patents-Global

2 Number of Fintech Patents-Asia and the Pacific

3 Competition-related Dynamics in the Provision of Fintech Services 11

4 Microfinancial Risks 12

5 Macrofinancial Risks 13

\section{FIGURES}

1 Major Technologies Transforming Financial Technologies 1

2 Global Fintech Patents by Jurisdiction 2

3 Top Fintech Patent Jurisdictions by Publication Year 3

4 Distribution of Major Fintech Innovators-Asia and the Pacific 5

5 The Supply and Demand Explanatory Matrix on Fintech Competition Issues 6

6 Financial Inclusion in Asia and the Pacific (\%, age 15+) 7

7 Individuals Using the Internet (\% of population) 8

8 Secure Internet Servers (per 1 million people) 8

9 The Demand versus Supply of Fintech By Country 9

\section{BOXES}

1 Alibaba-Paving the Way for Financial Inclusion through Fintech 10

2 ADB Approach to Improve Financial Inclusion $\quad 18$ 


\section{Foreword}

nnovation has consistently spurred economic growth and fostered development across Asia and the Pacific. From the "Green Revolution" in agriculture in the 1960s and 1970s to the spread of internet use today, applying technology to daily life promotes economic participation and inclusion. New technology offers unprecedented opportunities for lowincome and latecomer economies to leapfrog or catch up by adopting and innovating technologies to match their local market needs.

The spread of digital finance could dramatically expand access to financial services in the region-especially among the underserved population, among micro, small, and mediumsized enterprises (MSMEs), and in rural and agricultural areas. Also, finance today is being transformed by the so-called fourth industrial revolution: i.e., mobile technology, big data, blockchain's distributed ledger technology, cloud computing, and artificial intelligence including machine learning. The potential benefits from this transformation are huge, and the significant risks it brings must also be managed.

How Asia embraces these sophisticated technologies will help determine its economic future. There must be a concerted effort to foster an ecosystem that will promote sustainable, inclusive, and innovative growth. Yet it must also protect consumers and avoid the risks that could drive people away from embracing financial technology-such as cyber fraud, data security and privacy breaches, money laundering, and terrorism financing.

Governments can play a key role. They must provide the policy and regulatory environment that allows technological advancements to thrive. They must also establish appropriate policy and regulatory safeguards to ensure any disruption associated with new technology is managed and channeled in a way that increases competition, productivity, and innovationareas that support financial stability. In doing so, the region's governments must also work together to ensure their legal and regulatory frameworks are consistent, harmonized, and effective in managing associated risks with cross-border implications.

I hope this study-which presents the key facts, implications, challenges, and policy issues related to financial innovation - will contribute to a better understanding of the issues, raise the level of policy debate, and encourage new ways of making fintech an effective tool. The digital revolution is here, and we have only begun to explore its potential. To bridge the gap in understanding this rapidly evolving technology, we must learn, research, and innovate together.

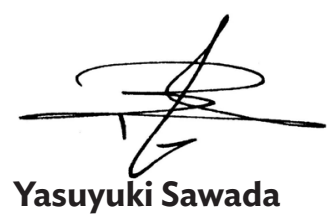

Chief Economist and Director General

Economic Research and Regional Cooperation Department

Asian Development Bank 


\section{Acknowledgments}

$\mathrm{T}$

his report was prepared by the Regional Cooperation and Integration (ERCI) Division of the Economic Research and Regional Cooperation Department, the Asian Development Bank (ADB) under RETA 9077: Enhancing Regional Capacity for Economic Surveillance and Financial Vulnerability Assessment with funding from the Investment Climate Facilitation Fund and the Government of Japan.

Cyn-Young Park, Director of ERCI led the preparation of this report with James Villafuerte and Bo Zhao as main contributors. The report also benefited from technical advice provided by Lotte Schou-Zibell, Chief of Finance Sector Group at ADB. Economic research and technical support was provided by Mara Claire Tayag, Clemence Fatima Cruz, Michael Angelo Cokee, Pilar Dayag, Jia Tang, and Chengcheng Liu.

Bo Zhao coordinated the production with support from Paulo Rodelio Halili, who provided other technical and administrative support.

James Unwin edited the manuscript and Michael Cortes implemented the typesetting, cover design, and graphics. The Printing Services Unit of ADB's Office of Administrative Services and the Publishing Team of the Department of Communications supported printing and publishing. 


\section{Executive Summary}

A sia and the Pacific continues to embrace advancements in digital technology that are shifting financial services from a traditional banking approach toward the decentralization and disintermediation of economic transactions. Financial technology, or fintech, as a redefined sector at the intersection of financial services and technology, has accelerated the leveraging of mobile internet access, cryptography, distributed computing, big data, and artificial intelligence that are bringing innovative applications across a large range of services, from payments to saving, borrowing, risk management, and financial advice.

Developing Asia has been growing rapidly while still saddled with relatively less inclusive financial systems. The rapid spread of financial technology offers great opportunity to reduce the cost of financial services. It can profitably boost financial inclusion and enable large productivity gains. These technological innovations have brought structural change to financial markets and increased sophistication in the delivery of financial products and services. These changes have also created new challenges for policymakers and financial regulators to better understand the growing complexity of financial products and servicesas well as to identify risks - which can be destructive.

This brief report documents facts of financial innovation in Asia and the Pacific that include:

- Fintech redefines a specific sector at the intersection of financial services and technology sectors.

- Country-level development-access to technology has grown rapidly in the region, and the +3 economies comprising of People's Republic of China, Japan, and the Republic of Korea have become the leading players in global fintech innovation.

- Service-level development-the application of mobile internet access to payment services is the most innovation active area, while the use of artificial intelligence, big data, and distributed computing to transform traditional banking services is also popular.

- Firm-level development-fintech innovations do not only come from technology start-ups, but also from large commercial banks, incumbent computer and software companies, and from manufacturers.

Based on these facts, the implications and challenges related to financial innovation in Asia and the Pacific include:

- Financial technology has the potential to improve and promote more inclusive finance in Asia.

- Fintech brings industry concentration in a market dominated by a few large companies. Competition policies and better allocation of resources are needed to avoid the monopolistic tendencies of technology giants and prevent abuse of market power.

- Fintech will transform the entire financial system, from money to infrastructure to fundraising, which requires careful analysis of underlying risks to financial stability.

- With machine learning and predictive analytics based on big data and artificial intelligence being applied to various financial services, data are more vulnerable to security breaches. Cybersecurity, privacy, know your customer, and consumer protection issues associated with fintech are critical.

- As changes in the financial sector accelerate toward the digitalization, decentralization, and disintermediation of economic transactions, money laundering, terrorist financing, and competition issues also require actions from regulators. 
This report also identifies the following key policy issues for central banks, government agencies, regulators, and international financial institutions:

- Issue 1: Managing technological innovation to promote greater financial inclusion.

- Issue 2: Developing the ecosystem to support the creation, diffusion, and scaling up of technology and innovation.

- Issue 3: Strengthening the role of central banks and financial regulators in managing risks and developing the regulatory environment to strike a balance between innovation and financial stability, and to protect consumers.

- Issue 4: Identifying the role of international financial institutions and regional cooperation in addressing challenges and vulnerabilities. 
efficiency and helped to reduce costs. Digitalization has been accompanied by decentralization and disintermediation. The distributed ledger is a salient example of decentralized services, and its applications include cryptocurrencies and smart contracts. New technology-driven business models, such as peer-to-peer platforms and robo-advisors, have supplanted some traditional financial intermediaries, posing distinct challenges for incumbent financial service providers and regulators.

\section{Fact 2: Country-level development-technology access has grown rapidly in Asia and the Pacific, and the +3 economies comprising the People's Republic of China, Japan, and the Republic of Korea have become the leading players in fintech innovation.}

By 2018, Asia and the Pacific has the largest proportion of fintech patents globally. More than $65 \%$ of global fintech patents have been filed in the region over the past 20 years. Fintech patent applications in the People's Republic of China (PRC), Japan, and the Republic of Korea comprised about $60 \%$ of the global total, while $23 \%$ were filed in the United States (Figure 2).

Figure 2: Global Fintech Patents by Jurisdiction

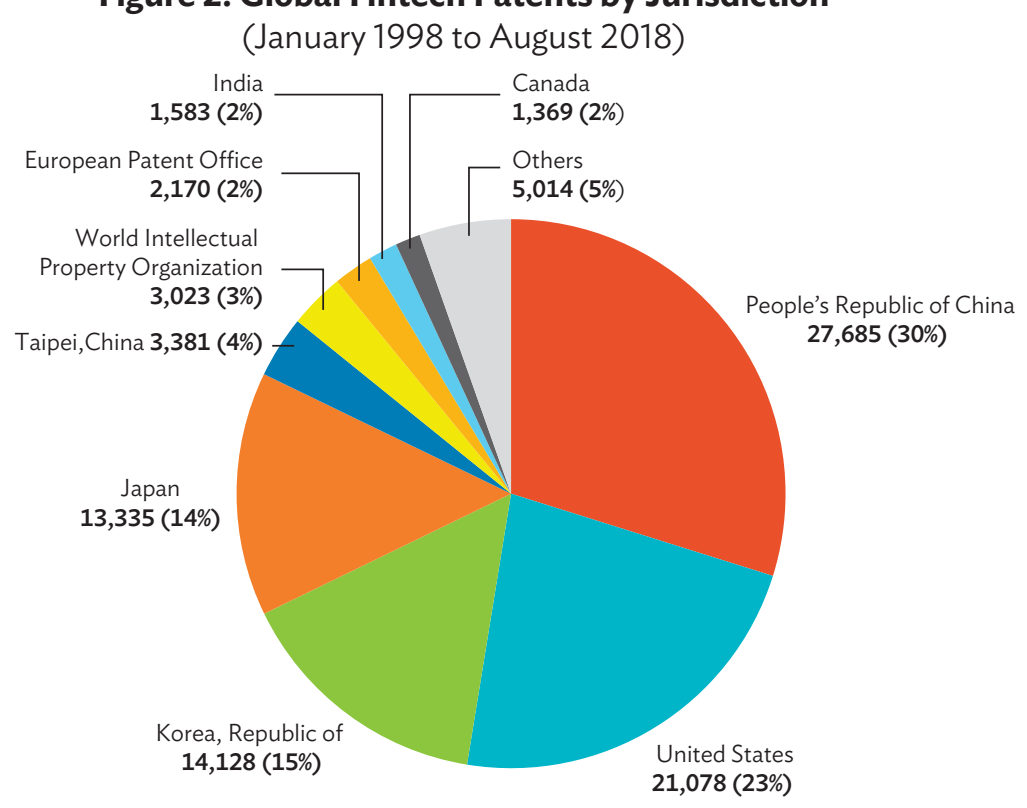

Source: ADB calculations based on patent data from Relecura.

In 1998, only 71 fintech patents were filed all over the world. By 2005, the United States had surpassed Japan as the largest fintech patent application jurisdiction. From 2005 to 2006, the Republic of Korea experienced $643 \%$ growth in the number of published fintech patents and became the largest until 2007. From 2008 to 2010, the United States and the PRC took turns to have the largest proportion. Meanwhile, the Republic of Korea kept steady growth in fintech filing while Japan experienced some fluctuations. Since 2011, the PRC has been the largest fintech patent jurisdiction, followed by the United States (Figure 3). 
Figure 3: Top Fintech Patent Jurisdictions by Publication Year (1998-2017)

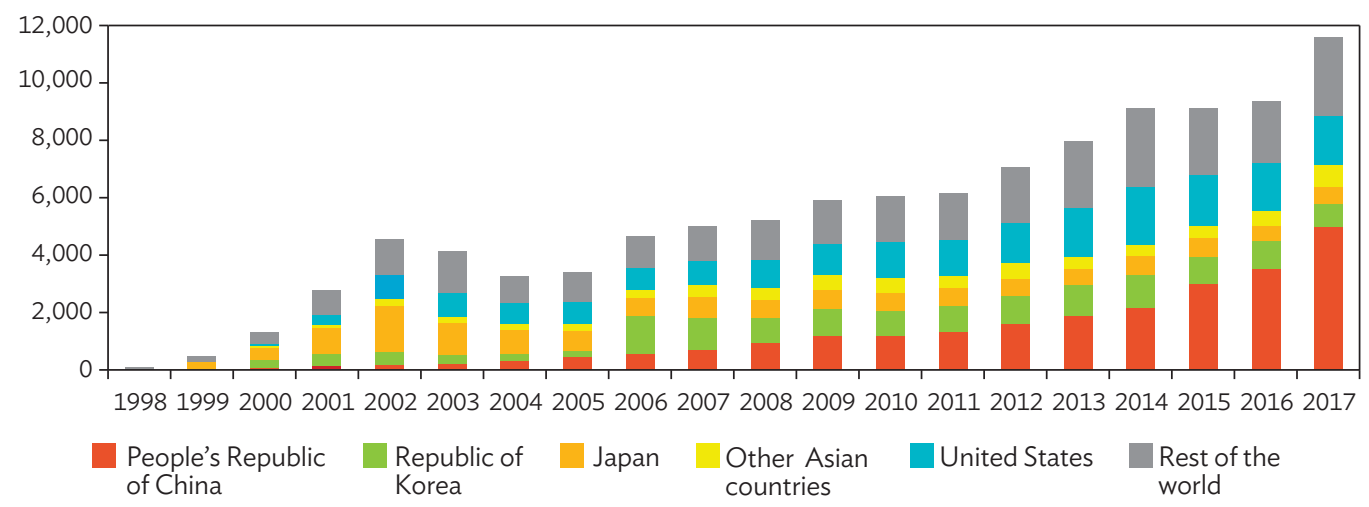

Source: ADB calculations based on patent data from Relecura.

East Asia is the most active area for fintech patents filing in Asia and the Pacific, while the PRC, the Republic of Korea, Japan, and Taipei,China contributed a combined 68\% of fintech patents in 2017 globally. More fintech patents are filed and published in the PRC than in any other jurisdiction, with its proportion of the total having increased from 30\% in 2013 to 51\% in 2017.

Fact 3: Service-level development-in Asia and the Pacific, the application of mobile internet access to payment services is the most innovation active area, while use of artificial intelligence, big data, and distributed computing to transform traditional banking service is also popular.

Based on the analytical framework of fintech (see Figure 1) proposed by the International Monetary Fund in 2017, which includes technology and financial service dimensions, the patterns of fintech innovation between the global pattern and Asia and the Pacific sample are similar.

The largest number of fintech patents is in the area of using mobile internet access technology for payment service (e.g., mobile payment), while cryptography technology used in advisory service has the least. From the technology dimension, the mobile internet is the highest utilized technology in fintech patents, and distributed computing technology comes second. From the financial services dimension, payment services have the largest number of fintech patents and savings services are second (Table 1).

Table 1: Number of Fintech Patents-Global (January 1998 to August 2018)

\begin{tabular}{|l|l|c|c|c|c|c|}
\hline \multicolumn{2}{|c|}{ Technology } & \multicolumn{5}{c|}{ Financial Services } \\
\hline \multicolumn{1}{|c|}{ Foundations } & \multicolumn{1}{|c|}{ Innovations } & Pay & Save & Borrow & $\begin{array}{c}\text { Manage } \\
\text { Risks }\end{array}$ & $\begin{array}{c}\text { Get } \\
\text { Advice }\end{array}$ \\
\hline $\begin{array}{l}\text { Artificial intelligence } \\
\text { Big data }\end{array}$ & $\begin{array}{l}\text { Machine learning } \\
\text { Predictive analytics }\end{array}$ & 4,755 & 4,429 & 3,963 & 3,576 & 130 \\
\hline Distributed computing & $\begin{array}{l}\text { Distributed ledger } \\
\text { (blockchain) }\end{array}$ & 9,995 & 9,158 & 8,484 & 6,020 & 308 \\
\hline Cryptography & $\begin{array}{l}\text { Smart contracts } \\
\text { Biometrics }\end{array}$ & 1,154 & 880 & 870 & 576 & 44 \\
\hline $\begin{array}{l}\text { Mobile Access } \\
\text { Internet }\end{array}$ & $\begin{array}{l}\text { Application } \\
\text { programming interface }\end{array}$ & 63,088 & 48,966 & 46,088 & 31,959 & 1,714 \\
\hline & Digital wallets & & & & \\
\hline
\end{tabular}


Payments technology is so fundamental and widely applied that it is still growing strongly after decades of development. In recent years, much attention and investment has been drawn to emerging Asia, where mobile payments could help many people, including those in rural areas, access affordable financial products and services-transactions, payments, savings, credit, and insurance. Besides mobile payments, more recent high-growth fintech segments include peer-topeer lending, savings, and investment advice. In Asia and the Pacific, except for patents related to cryptography technology, other categories make up more than $50 \%$ of the global share of fintech patents (Table 2).

Table 2: Number of Fintech Patents-Asia and the Pacific (January 1998 to August 2018)

\begin{tabular}{|c|c|c|c|c|c|c|}
\hline \multicolumn{2}{|c|}{ Technology } & \multicolumn{5}{|c|}{ Financial Services } \\
\hline Foundations & Innovations & Pay & Save & Borrow & $\begin{array}{l}\text { Manage } \\
\text { Risks }\end{array}$ & $\begin{array}{c}\text { Get } \\
\text { Advice }\end{array}$ \\
\hline $\begin{array}{l}\text { Artificial Intelligence } \\
\text { Big Data }\end{array}$ & $\begin{array}{l}\text { Machine learning } \\
\text { Predictive analytics }\end{array}$ & 3,438 & 3,274 & 2,870 & 2,123 & 103 \\
\hline $\begin{array}{l}\text { Distributed } \\
\text { Computing }\end{array}$ & $\begin{array}{l}\text { Distributed ledger } \\
\text { (Blockchain) }\end{array}$ & 5,751 & 5,364 & 4,789 & 3,244 & 214 \\
\hline \multirow[t]{2}{*}{ Cryptography } & Smart contracts & \multirow[t]{2}{*}{605} & \multirow[t]{2}{*}{439} & \multirow[t]{2}{*}{426} & \multirow[t]{2}{*}{276} & \multirow[t]{2}{*}{24} \\
\hline & Biometrics & & & & & \\
\hline \multirow[t]{2}{*}{$\begin{array}{l}\text { Mobile Access } \\
\text { Internet }\end{array}$} & $\begin{array}{l}\text { Application } \\
\text { programming interface }\end{array}$ & \multirow[t]{2}{*}{43,604} & \multirow[t]{2}{*}{33,360} & \multirow[t]{2}{*}{30,907} & \multirow[t]{2}{*}{20,863} & \multirow[t]{2}{*}{1,266} \\
\hline & Digital wallets & & & & & \\
\hline
\end{tabular}

Source: ADB calculations based on patent data from Relecura.

Fact 4: Firm-level development: Fintech innovations do not only come from technology start-ups, but also from large commercial banks, incumbent computer and software companies, and manufacturing firms. Fintech brings some industry concentration and the market is dominated by a few large companies in Asia and the Pacific.

The fintech patents landscape in Asia and the Pacific comprises traditional manufacturing firms, commercial banks, internet companies, telecommunication firms, and pure fintech companies. As presented in the distribution of major Fintech innovators in Figure 4, except for obvious clusters of different types of companies, some bubbles are close to each other, which indicates that these companies have similar innovations. 
Figure 4: Distribution of Major Fintech Innovators-Asia and the Pacific

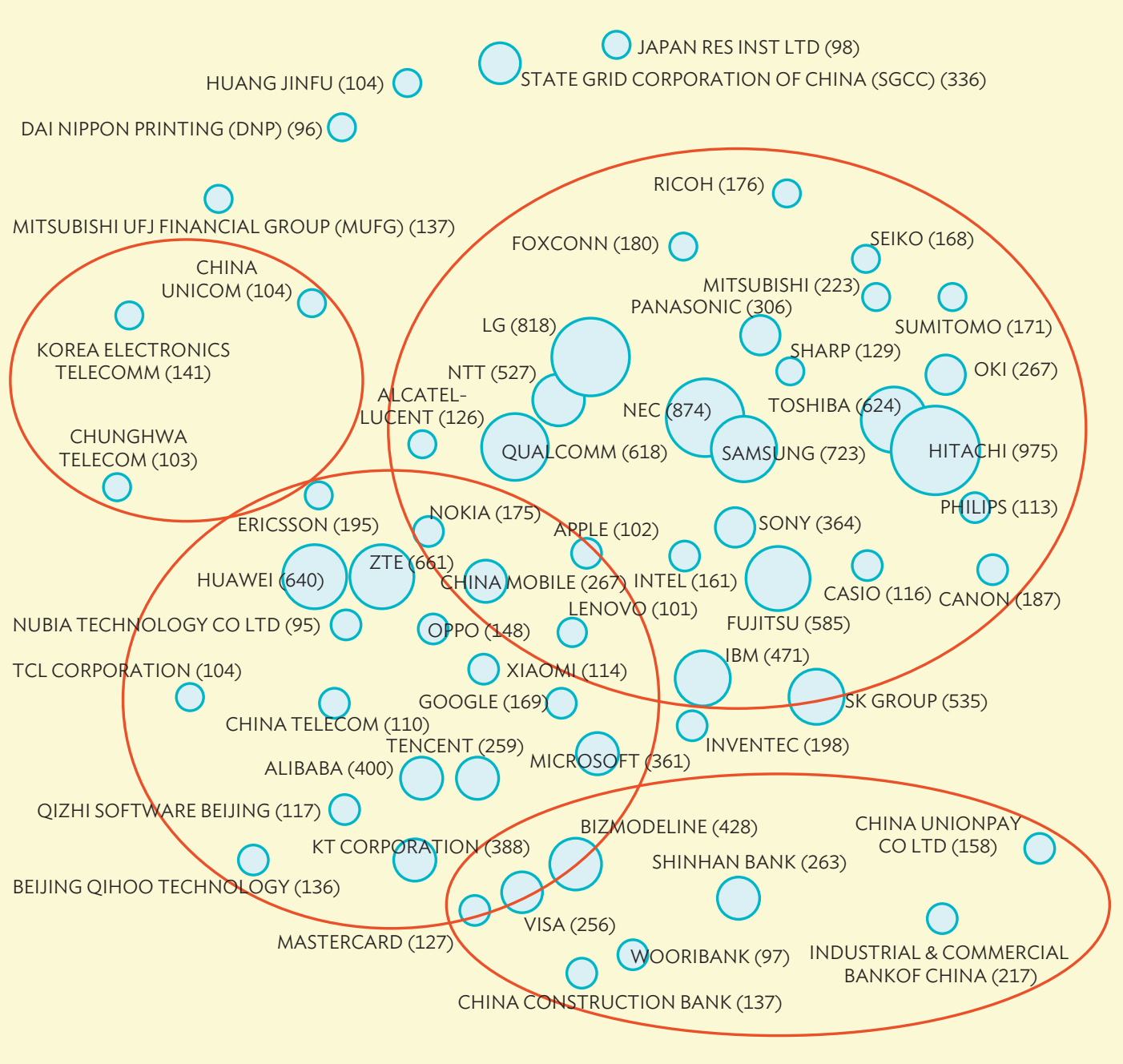

Note: Topic maps are visual landscape of the results set based on various patent parameters and help in identifying the technology clusters. The bubble size indicates the number of the patents and the proximity of the bubbles represents the similarity of technology in the bubble. Source: Relecura.

Fintech's competition challenges can be examined from the supply-side and the demand-side (European Parliament 2018). From a supply-side perspective, which is mainly about the type of technology used to charaterize a financial service, platform technologies and access to data could bring competition problems since the network effects from both may intensify market concentration. From the demand-side, which is mainly based on the perspective of the user of technology, access and operation and user perceptions and behavior should be considered (Figure 5). Both sides may bring new competition challenges that mark a departure from traditional financial services or introduce technology sector competition problems.

Large tech companies, whose advanced technologies look suited to entrenching their positions, are creating more competition problems than fintech start-ups. Payment services, as the most mature category of fintech services, gather a large amount of customer data that can be used by providers of payment services to leverage their positions. Firms with an established place in the market, such as Alibaba and Tencent in the PRC, have a strong incentive to lock-in customers and use payment services as the starting point to sell other services. 
Figure 5: The Supply and Demand Explanatory Matrix on Fintech Competition Issues

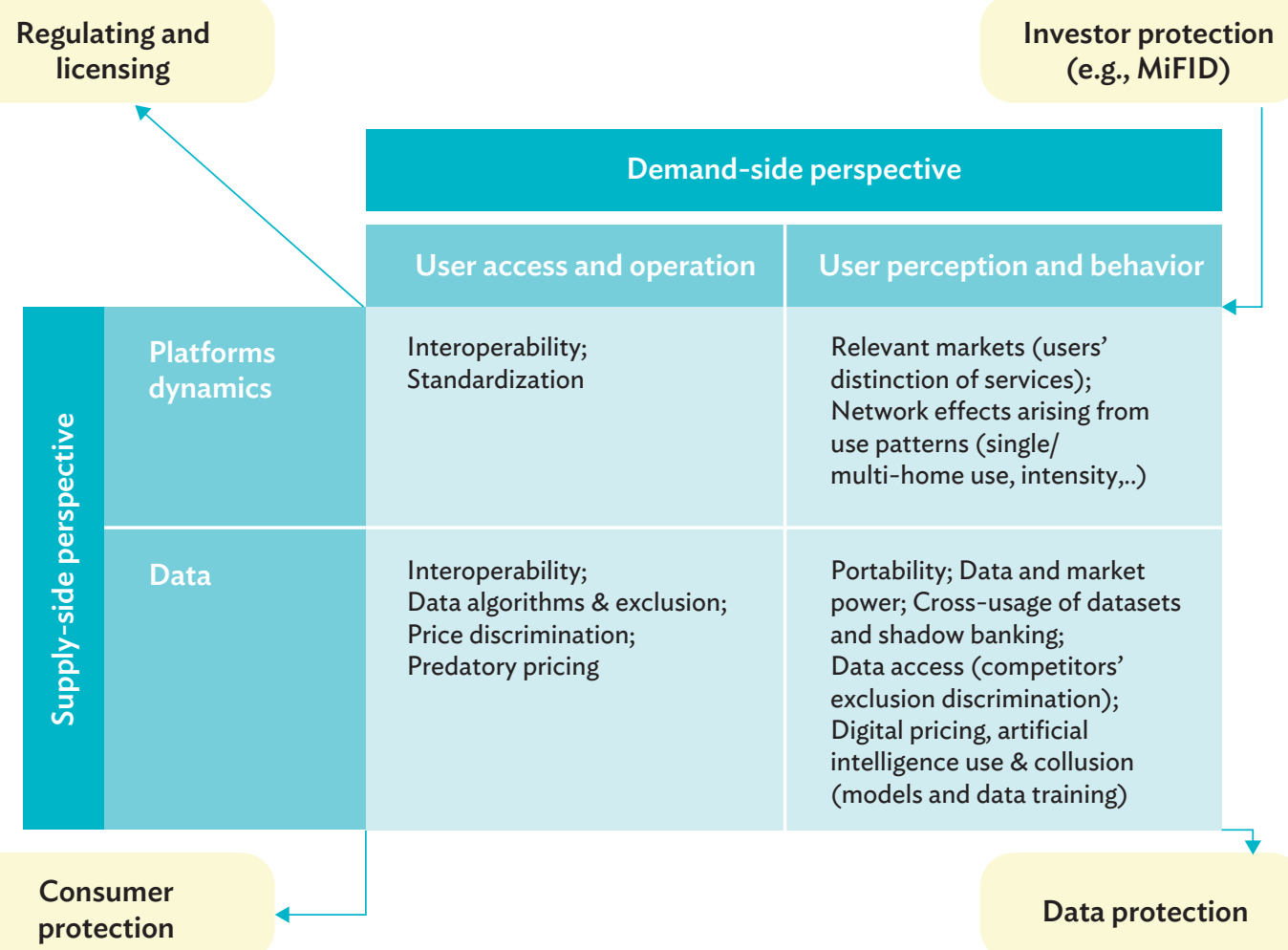

Note: The markets in financial instruments directive (MiFID) is a regulation that increases the transparency across the European Union's financial markets and standardizes the regulatory disclosures required for particular markets. Source: European Parliament (2018). 
Branchless banking, using agents and relying on information and communications technologies to transmit transaction details, could help provide greater access for the poor. Pervasive mobile phone access in Asia (with 4.1 billion people having access to mobile phones) can help increase access to finance for 1 billion unbanked adults in the region. The number of internet users in Asia has grown rapidly from less than $1 \%$ of the total population before 1998 to $16 \%-58 \%$ in 2016, depending on the geographic region. East Asia takes the lead, while Central Asia trails (Figure 7).

Figure 7: Individuals Using the Internet (\% of population)

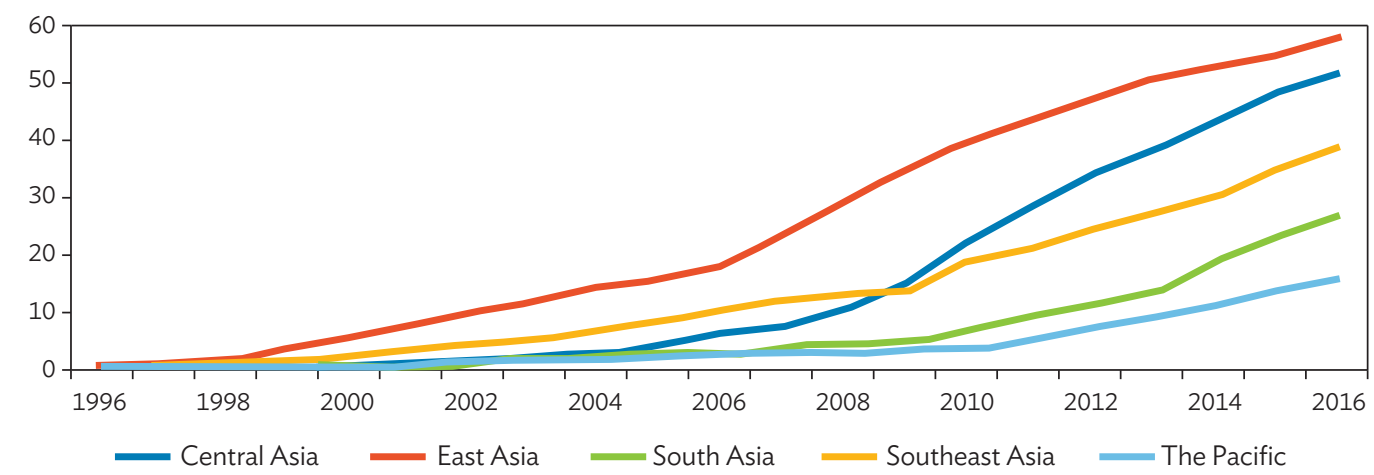

Source: ADB calculations using data from World Development Indicators, World Bank.

Also, secure internet servers are more accessible to users in East Asia than in other parts of Asia (Figure 8). Geographic disparities exist in these fundamental internet infrastructures that are essential for fintech development and applications.

Figure 8: Secure Internet Servers (per 1 million people)

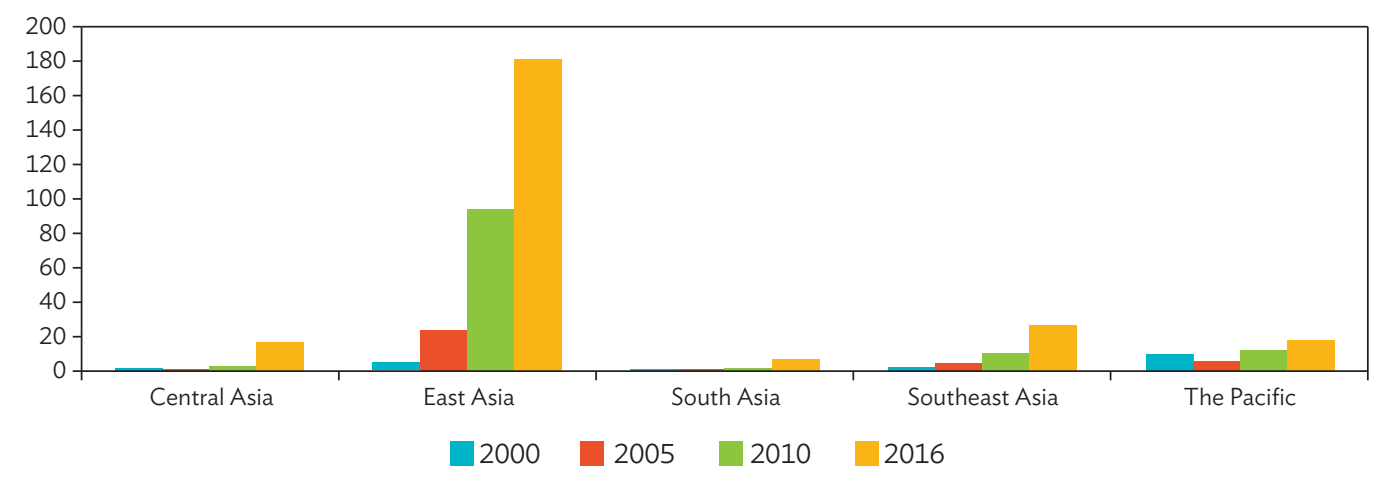

Source: ADB calculations using data from World Development Indicators, World Bank.

Improved infrastructure-through investment in transportation, enery, credit information services, and telecommunications - can help banks reach the poor. New technologies gather and analyze more and better data, which reduces information asymmetry and helps address the issue of financial inclusion in the region. Big data and fintech can offer good substitutes for traditional credit bureaus or credit registries in places where these systems are non-existent or work inefficiently. This could impact credit information assessment and sharing in countries accounting for half of the world's population, providing a boost for financial inclusion (PERC 2016).

Policy options and reforms are needed to create an enabling environment for fintech to serve households and MSMEs. It is also helpful to improve financial literacy and empower consumers and MSMEs through financial education in a fast-evolving fintech world. 
Many Asian governments have been taking initiatives to utilize fintech to improve access to financial services for the poor. A successful example is Bangladesh's Mobile Financial Services program. Led by banks, it aims to reach virtually the whole population, including those in remote areas. Mobile Financial Services clients have grown to 42 million in 2017 from its start in 2011. Now $80 \%$ of rickshaw pullers in Dhaka use the program to send money regularly to their families in remote areas of the country.

India has taken initiatives such as Jan Dhan Yojana, Aadhaar and United Payments Interface (UPI) to support fintech development and boost financial inclusion across the country. Pradhan Mantri Jan Dhan Yojana is a government program that aims to expand access to financial services and make it affordable for the large unserved or underserved population in India. Aadhaar is another government program that collects residents' biometric and demographic data. Using Aadhaarbased biometric authentication, financial services companies can perform e-Know Your Customer (e-KYC) checks more economically and reduce transaction costs. The Aadhaar program has boosted financial inclusion, with more than 1 billion people enrolled for accounts (World Economic Forum 2016). UPI is introduced by the National Payments Council of India to facilitate peer-topeer transactions and transactions across banks (PWC 2017a).

Low-income countries often have the greatest need to improve financial inclusion, while the fintech infrastructure and ecosystem evolve as countries become richer. Poorer countries, where bank branches are few and mainly concentrated in urban areas, have larger underserved populations than richer countries. Setting up bank branches is costly, especially in rural areas. Therefore, expansion of the traditional banking system is unlikely to serve people in poor countries very well, and the need for fintech-led financial inclusion is urgent (ING 2016). Figure 9 indicates that many low-income and lower-middle-income countries, such as Pakistan (PAK in the figure) and Nepal (NEP), are at the higher half of the graph, while richer economies such as the PRC and Thailand (THA) are located at the lower half of the graph.

\section{Figure 9: The Demand versus Supply of Fintech By Country}

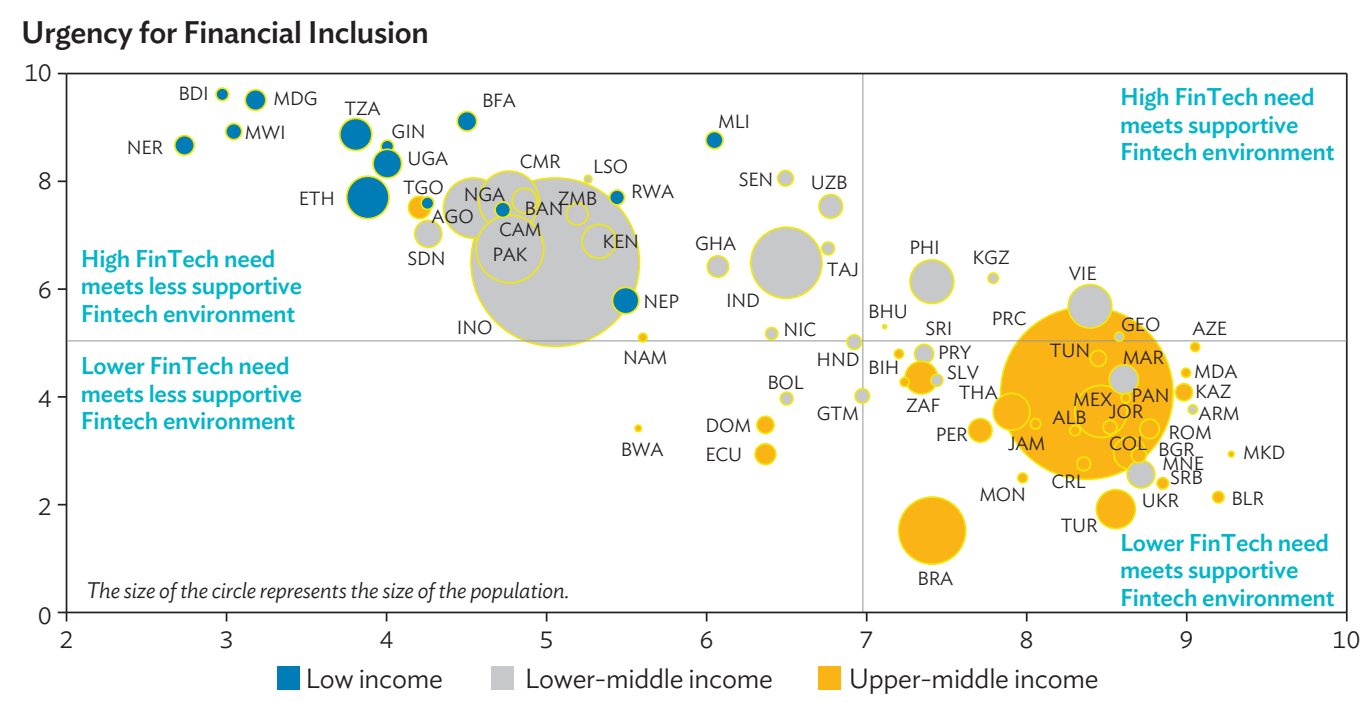

$\mathrm{AGO}=$ Angola, $\mathrm{ALB}=$ Albania, $\mathrm{ARM}=$ Armenia, $\mathrm{AZE}=$ Azerbaijan, $\mathrm{BAN}=$ Bangladesh, $\mathrm{BDI}=\mathrm{Burundi}, \mathrm{BFA}=\mathrm{Burkina}$ Faso, $\mathrm{BGR}=$ Bulgaria, $\mathrm{BHU}=$ Bhutan, $\mathrm{BIH}=$ Bosnia and Herzegovina, $\mathrm{BLR}=$ Belarus, $\mathrm{BOL}=$ Bolivia, $\mathrm{BRA}=\mathrm{Brazil}, \mathrm{BWA}=\mathrm{Botswana}, \mathrm{CAM}=\mathrm{Cambodia}$, $\mathrm{CMR}=$ Cameroon, $\mathrm{COL}=$ Colombia, $\mathrm{CRI}=$ Costa Rica, $\mathrm{DOM}=$ Dominican Republic, $\mathrm{ECU}=$ Ecuador, ETH $=$ Ethiopia, $\mathrm{GEO}=\mathrm{Georgia}$, GHA = Ghana, GIN = Guinea, GTM = Guatemala, HND = Honduras, IND = India, INO = Indonesia, JAM = Jamaica, JOR = Jordan, $\mathrm{KAZ}=$ Kazakhstan, $\mathrm{KEN}=$ Kenya, $\mathrm{KGZ}=$ Kyrgyz Republic, $\mathrm{LSO}=$ Lesotho, $\mathrm{MAR}=$ Morocco, $\mathrm{MDA}=$ Moldova, $\mathrm{MDG}=\mathrm{Madagascar}$, MEX = Mexico, $M K D=$ Macedonia,$M L I=$ Mali, $M N E=$ Montenegro, $M O N=$ Mongolia,$M W I=$ Malawi $, N A M=N a m i b i a, N E P=N e p a l, N E R=N i g e r$, $\mathrm{NGA}=$ Nigeria, $\mathrm{NIC}=$ Nicaragua, $\mathrm{PAK}=$ Pakistan, $\mathrm{PAN}=$ Panama, $\mathrm{PER}=$ Peru, $\mathrm{PHI}=$ Philippines, $\mathrm{PRC}=$ People's Republic of China, $\mathrm{PRY}=\mathrm{Paraguay}$, ROM = Romania, $\mathrm{RWA}=$ Rwanda, $S D N=$ Sudan, $S E N=$ Senegal, SLV = EI Salvador, SRB = Serbia, SRI = Sri Lanka, TAJ = Tajikistan, $T H A=T$ Thailand, $\mathrm{TGO}=$ Togo, $\mathrm{TUN}=$ Tunisia, $\mathrm{TUR}=$ Turkey, $\mathrm{TZA}=$ Tanzania, $\mathrm{UGA}=$ Uganda, UKR = Ukraine, UZB = Uzbekistan, VIE = Viet Nam, ZAF = South Africa, $\mathrm{ZMB}=$ Zambia. Source: ING (2016).

Source: http://asiancenturyinstitute.com/economy/1414-fintech-in-asia 


\section{Box 1: Alibaba-Paving the Way for Financial Inclusion through Fintech}

The World Bank describes financial inclusion as a state where "individuals and businesses have access to useful and affordable financial products and services that meet their needs - transactions, payments, savings, credit and insurance-delivered in a responsible and sustainable way." Meanwhile, the Financial Stability Board defines fintech as "technologically enabled financial innovation that could result in new business models, applications, processes, or products with an associated material effect on financial markets and institutions and the provision of financial services." With these definitions in mind, it is unsurprising to see how Alibaba, since it was established in 1999, has paved the way to greater financial inclusion through fintech, especially in the People's Republic of China (PRC). It has expanded the reach of financial products and services at an unprecedented scale and unparalleled pace through innovations in electronic commerce (e-commerce), nonbank digital payment systems, internet banking, credit reference and internetbased microlending, insurance, and wealth management.

\section{E-Commerce}

The company's major online marketplaces include the English-language international marketplace that brings together importers and exporters from more than 240 countries and regions; and the Taobao marketplace, the biggest consumer-to-consumer online shopping platform in the PRC. Taobao is estimated to have helped create 2.67 million jobs directly through business growth, as well as indirect job formation through Taobao's collaboration with logistics companies and other partners. ${ }^{c}$

\section{Nonbank digital payment}

Alibaba's first foray into financial products was Alipay, launched in 2004. Alipay provided a breakthrough payment service for Taobao called "escrow", which allows consumers to verify whether they are satisfied with the goods before releasing payment to the seller. This arrangement addresses a fundamental issue that hampered e-commerce in the PRC in its early days: lack of trust between buyers and sellers. ${ }^{d}$ The number of Alipay's annual active users reached 451 million in 2015, while average daily transactions numbered 153 million. ${ }^{\text {e }}$

Building off the core Alipay platform, Alibaba launched Ant Financial in October 2014 to provide a range of financial services spanning payment, investment and financial management, insurance, and microlending.

\section{Internet-based microlending}

Ant Financial's internet-based micro lending can be roughly broken down as:

1. Financing for online store operators.

2. Consumer lending for online shoppers.

3. Small loans to agricultural households.

Ant Financial had extended 3 million loans to small and medium-sized enterprises (SMEs) as of 16 March 2016.

\section{Internet banking}

Alibaba's Ant Financial ventured into internet banking through the establishment of MYbank in 2015. MYbank has no outlets or counter services. Its credit products targets individuals and small firms. By the end of 2016, the internet bank's loan balance to SMEs (including personal businesses) had reached $\$ 4.3$ billion. ${ }^{d}$

\section{Internet-based fund management}

Ant Financial launched its Yuebao internet-based fund management product in June 2013. Accessed via Alipay, Yuebao was developed to mobilize funds sitting dormant in millions of Alipay accounts, with returns on investments passed on to account holders. As of the end of 2016, the number of customers had grown to 324.6 million and funds under management reached $\$ 121$ billion. ${ }^{d}$

\section{Credit reference}

Using big data derived from its online trading activities, Alibaba was able to a build its own credit scoring model that profiles client behaviors, characteristics, and needs. As of March 2016, cumulative users of Alibaba's credit reference numbered 130 million. ${ }^{\circledR}$

In summary, Alibaba's success and contribution to financial inclusion came from (i) its focus on small enterprises and individuals; (ii) its ability to build efficiency and cut the costs of intermediaries; (iii) leveraging technology effectively to provide greater options to consumers; (iv) the use of big data to understand consumer behavior, and (v) its protection of consumer interests.

World Bank. Financial Inclusion. http://www.worldbank.org/en/topic/financialinclusion/overview\#1.

Financial Stability Board. Monitoring of Fintech. http://www.fsb.org/what-we-do/policy-development/additional-policy-areas/monitoring-of-fintech/.

Shrader, L. 2013. Microfinance, E-Commerce, Big Data and China: The Alibaba Story. Consultative Group to Assist the Poor (CGAP) Blog. 11 October. http://www.cgap. org/blog/microfinance-e-commerce-big-data-and-china-alibaba-story.

d World Bank Group and the People's Bank of China. 2018. Toward Universal Financial Inclusion in China: Models, Challenges, and Global Lessons. Washington DC: International Bank for Reconstruction and Development/ The World Bank and the People's Bank of China.

e Ant Financial. Infographic: Our Vision. https://www.alibabagroup.com/en/ir/pdf/160614/12.pdf. 


\section{Competition policies and better resource allocation are needed to avoid the monopolistic tendencies of technology giants and prevent abuse of market power.}

Research shows that competition is a potential determinant of innovation (Aghion et al. 2005). European Parliament (2018) summarizes the competitive landscape of fintech services (Table 3). The column "Causes" reflects potential dynamics that might lead to anticompetitive practices. The column "Problems" includes classic competition issues that may affect the categories of fintech services listed in the following columns. The green color indicates causes of competition problems that impact certain categories of services. The light gray color implies that a cause does not affect a particular service.

In bank lending and payment services, significant challenges in the development of a competitive market may occur for a number of reasons. Since potential fintech players may face a high entry barrier and significant compliance costs, the services will more likely to be provided by a few large companies. Market concentration will lead to collusive agreement and high profits, which these large companies may use to keep the entry barrier high and maintain their dominant positions. As other causes may also raise competitive issues, fintech competition policies and better resource allocation are needed, consistent with development objectives for inclusive growth.

Table 3: Competition-related Dynamics in the Provision of Fintech Services

\begin{tabular}{|c|c|c|c|c|c|c|c|c|c|c|c|}
\hline \multirow{2}{*}{\multicolumn{3}{|c|}{ Causes }} & \multirow[b]{2}{*}{ Problems } & \multicolumn{2}{|c|}{ Banking } & \multirow[b]{2}{*}{ 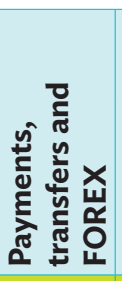 } & \multirow{2}{*}{ 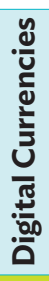 } & \multirow{2}{*}{ 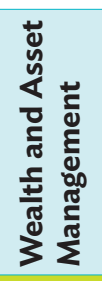 } & \multirow[b]{2}{*}{ 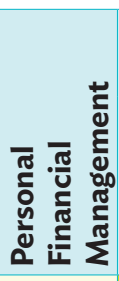 } & \multirow[b]{2}{*}{ 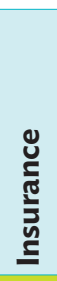 } & \multirow{2}{*}{ 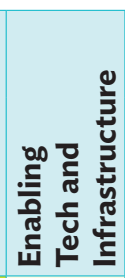 } \\
\hline & & & & 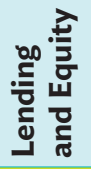 & $\begin{array}{l}\frac{n}{n} \\
\frac{\cos }{0} \\
\frac{0}{0}\end{array}$ & & & & & & \\
\hline \multirow{11}{*}{ 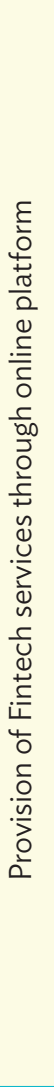 } & \multirow{11}{*}{ 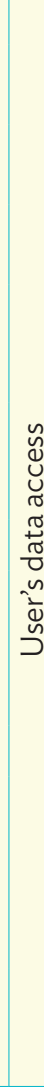 } & Licenses & \multirow{3}{*}{$\begin{array}{l}\text { Entry } \\
\text { costs and } \\
\text { maintenance } \\
\text { obligations } \\
\text { (compliance) }\end{array}$} & & & & & & & & \\
\hline & & $\begin{array}{l}\text { Prudential and } \\
\text { conduct rules }\end{array}$ & & & & & & & & & \\
\hline & & $\begin{array}{l}\text { Regulatory } \\
\text { asymmetry }\end{array}$ & & & & & & & & & \\
\hline & & $\begin{array}{l}\text { Technical } \\
\text { standardization }\end{array}$ & \multirow{3}{*}{$\begin{array}{l}\text { Collusive } \\
\text { agreements }\end{array}$} & & & & & & & & \\
\hline & & $\begin{array}{l}\text { Tying and } \\
\text { bundling } \\
\text { agreements }\end{array}$ & & & & & & & & & \\
\hline & & $\begin{array}{l}\text { Information } \\
\text { exchange } \\
\text { agreements }\end{array}$ & & & & & & & & & \\
\hline & & Network effects & \multirow{4}{*}{$\begin{array}{l}\text { Dominant } \\
\text { position and } \\
\text { its abuse }\end{array}$} & & & & & & & & \\
\hline & & $\begin{array}{l}\text { Pricing } \\
\text { strategies } \\
\text { (predatory, } \\
\text { excessive..) }\end{array}$ & & & & & & & & & \\
\hline & & Denial of access & & & & & & & & & \\
\hline & & $\begin{array}{l}\text { Intellectual } \\
\text { and industrial } \\
\text { property- } \\
\text { proprietary } \\
\text { technologies }\end{array}$ & & & & & & & & & \\
\hline & & Network effects & $\begin{array}{l}\text { Market } \\
\text { concentration } \\
(M \& A)\end{array}$ & & & & & & & & \\
\hline
\end{tabular}


With so much interest and so many potential uses, many argue that fintech will transform the entire financial system in Asia and the Pacific, from money to infrastructure to fund-raising. This requires careful analysis of underlying risks to financial stability.

The fintech industry can affect financial stability. Regulators can assess risks from emerging fintech innovations to financial stability from two aspects-microfinancial risks and macrofinancial risks. Microfinancial risks are those that make firms, financial market infrastructures (FMIs), or sectors particularly vulnerable to shocks (Table 4). Such risks could have a systemic impact if it triggers distress in firms or across the financial sector. Macrofinancial risks are system-wide vulnerabilities that can amplify shocks to the entire financial system and so increase the likelihood of financial instability across the economy (Table 5). These risks are largely related to interactions between firms, investors, and clients that create important transmission channels (Financial Stability Board 2017).

Table 4: Microfinancial Risks

\begin{tabular}{|c|c|c|}
\hline & Potential risk & Link to financial stability \\
\hline \multirow{3}{*}{ 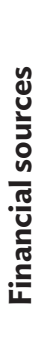 } & Maturity mismatch & $\begin{array}{l}\text { Arises when a loan is extended for a longer period than the financing is } \\
\text { contracted for, creating rollover risks. Systemic impacts could occur if the } \\
\text { sector provides critical functions or services. }\end{array}$ \\
\hline & Liquidity mismatch & $\begin{array}{l}\text { Happens when assets and liabilities have different liquidity } \\
\text { characteristics, resulting in "run risk" and the need to liquidate illiquid } \\
\text { assets quickly (a fire sale), which disrupts markets. }\end{array}$ \\
\hline & Leverage & $\begin{array}{l}\text { Higher leverage implies that less equity is available to absorb losses when } \\
\text { market, credit, or other risks materialize. This can expose systemically } \\
\text { important counterparties to losses. }\end{array}$ \\
\hline \multirow{5}{*}{ 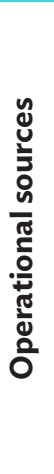 } & $\begin{array}{l}\text { Governance/process } \\
\text { control }\end{array}$ & $\begin{array}{l}\text { Poor governance or process control can increase the risk of direct } \\
\text { disruption in the provision of financial services or critical infrastructure. }\end{array}$ \\
\hline & Cyber risks & $\begin{array}{l}\text { The susceptibility of financial activity to cyberattacks is likely to be higher } \\
\text { the more that the systems of different institutions are connected. }\end{array}$ \\
\hline & Third-party reliance & $\begin{array}{l}\text { Systemic risks may arise when systemically important institutions or } \\
\text { markets rely on the same third parties. }\end{array}$ \\
\hline & Legal/ regulatory risk & $\begin{array}{l}\text { Legal/regulatory risk may increase when activities are evolving, or where } \\
\text { regulatory arbitrage is sought. Uncertainty around who has liability for } \\
\text { losses may be particularly damaging to confidence in the system. }\end{array}$ \\
\hline & $\begin{array}{l}\text { Business risk of critical } \\
\text { financial market } \\
\text { infrastructures (FMIs) }\end{array}$ & $\begin{array}{l}\text { An FMI may be vulnerable to external factors that could hurt its balance } \\
\text { sheet and so lead it to withdraw financial services, impairing its function } \\
\text { as a critical part of the financial infrastructure within an economy. }\end{array}$ \\
\hline
\end{tabular}

Source: Financial Stability Board (2017). 
Table 5: Macrofinancial Risks

\begin{tabular}{|l|l|}
\hline \multicolumn{1}{|c|}{ Potential risk } & \multicolumn{1}{|c|}{ Link to financial stability } \\
\hline Contagion & $\begin{array}{l}\text { Distress experienced by a single financial institution or sector can be } \\
\text { transmitted to other institutions or sectors owing either to direct exposure } \\
\text { between them, or commonalities that lead to a general loss of confidence in } \\
\text { those institutions or sectors. }\end{array}$ \\
\hline Procyclicality & $\begin{array}{l}\text { Market participants can act in ways that exacerbate the impact of fluctuations } \\
\text { in economic growth and market prices over the short and long terms. Examples } \\
\text { include: excess provision of credit by banks during upswings in an economy and } \\
\text { the extreme degree of deleveraging that tends to occur in a downswing, when } \\
\text { capital positions are threatened; the low pricing of risk in financial markets } \\
\text { during good times, and the high risk premia demanded by investors during bad } \\
\text { times. }\end{array}$ \\
\hline Excess volatility & $\begin{array}{l}\text { The financial system can overreact to news. This can produce adverse } \\
\text { outcomes if, for example, overreaction creates solvency or liquidity problems } \\
\text { that can spiral through the financial system, impairing the functioning of asset } \\
\text { and credit markets. This is most likely to occur when there is homogeneity of } \\
\text { business models or common exposures. }\end{array}$ \\
\hline Systemic importance & $\begin{array}{l}\text { Entities viewed as being systemically important (or too big and connected to } \\
\text { fail) may amplify risks through moral hazard. For example, they may be more } \\
\text { inclined to take on excessive risk, given that the downside to doing so is likely } \\
\text { limited by the implicit guarantee of public support. Predatory pricing of services } \\
\text { could also stifle competition ("the winner takes all"), reducing the likelihood } \\
\text { that other service providers will step in when the entity suffers distress. }\end{array}$ \\
\hline
\end{tabular}

Source: Financial Stability Board (2017).

\section{The fast dissemination of data, its gigantic size, and the complicated connections within networks pose security challenges for both the financial services industry and regulators.}

With machine learning and predictive analytics based on big data and artificial intelligence being applied in various financial services, data are more vulnerable to security breaches. Cybersecurity, privacy, know your customer, and consumer protection issues associated with fintech should be taken seriously. For example, there have been multiple cases of digital wallets being hacked and consumers losing a lot of money. Investigations into such cases usually take a long time and it is hard to identify the individuals or entities responsible.

Besides cybersecurity, data collection and data privacy are another concern caused by the integration of advanced technology with traditional systems. Financial services providers deal with sensitive information about individuals and enterprises. The establishment of data ownership therefore brings up both technical and legal questions. Improved access to financial services through technology may also increase the risk of exploitation of vulnerable customers. Fintech companies need to develop technologies to manage the data lifecycle so that data is not abused. Regulators should have regular discussions with fintech entrepreneurs and ensure adequate customer and investor protection. For example, regulators need to contemplate questions such as whether third parties have the right to access customer data and the ability and will to protect privacy, or whether customers are aware of this and consent to their online behavior being monitored. 


\section{As changes in the financial sector accelerate toward the digitalization, decentralization, and disintermediation of economic transactions, money laundering, terrorist financing, and anti-competition using fintech also requires action from regulators.}

Fintech companies, which are often not covered by traditional rules and laws, may not comply with anti-money-laundering and anti-terrorist-financing legislation. Indeed, innovative technologies are bringing new methods and tools for criminal activity. New vulnerabilities could develop as financial products such as cryptocurrencies, and technologies such as decentralized distributed ledgers serve anonymous users without accountability. Fintech creates a growing number of financial players and facilitates cross-border transactions, which creates more complexity for financial service providers and regulators to deal with when they monitor these activities.

When fintech companies are not covered by traditional financial sector regulations and competition policies, the potential risk increases and distortions in competition may deepen. ${ }^{2}$ Lawmakers should stay vigilant about these new developments and keep regulations up to date. Regulators should pay special attention to small and start-up fintech companies, which often lack the capacity and expertise to adequately examine users and trace the origin of their funds. 


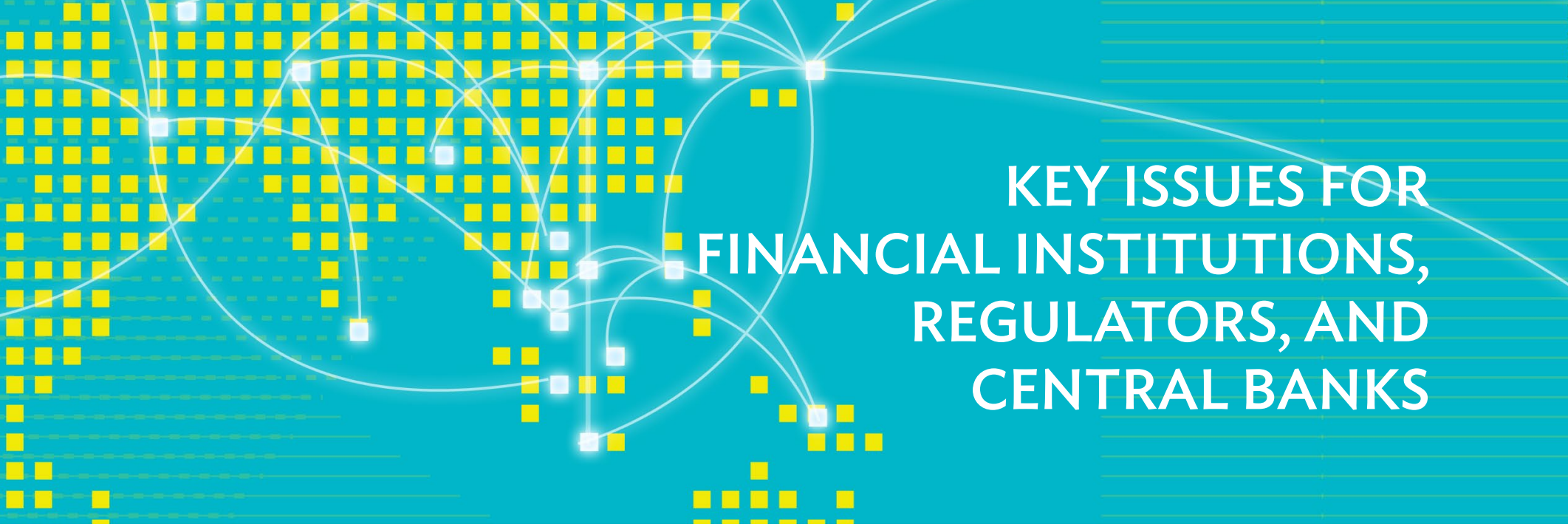

Issue 1: Managing technological innovation to promote greater financial inclusion.

Exponential growth in the integration of new technologies, the use of computational power, and the application of data with machine learning is happening in almost all facets of the world's financial markets and systems. This massive change is transforming the way payment services are delivered, savings and credit are mobilized, business risks are managed, and investment advice is given. These new technologies have dramatically mitigated asymmetric information and reduced transaction cost to provide better financial service to underserved population and companies (Mbiti and Weil 2013, Jack and Suri 2014).

Despite the myriad of associated technological advancements, 2 billion out of the world's 7 billion do not have access to financial services and 1 billion are in Asia. Moreover, technological innovation seems to be more concentrated geographically than income or wealth, and controlled by a few large companies. However, it is important that people have open access to use technology in everyday life as access to digital technology and improving digital fluency is important in promoting greater equality.

Are all the benefits of financial innovation being realized, especially for MSMEs, and what can be done about this? How can it be ensured that fintech innovations assist people currently excluded from financial services, helping them to engage in economic activities and to enjoy the growth benefits of the digital technology? How can digital infrastructure be developed to reach the remotest of communities? How to build a harmonized national or global digital identity system for people and firms to facilitate their access to financial services?

These are some important questions to answer if fintech innovation is to help deliver financial inclusion and inclusive growth in Asia.

Issue 2: Developing the ecosystem to support the creation, diffusion, and scaling up of technology and innovation.

Generally, two key components are driving technological revolution and innovation. First is the invention and the creation of the technology or innovative products and services themselves. Second is the way these innovations are diffused, which involves the introduction of enhancements and customization to match different settings and needs. Encouraging these aspects of innovation and activities has become a major focus for policymakers, and government can play a key role in harnessing technology for more inclusive finance (ADB 2018). 
The rationale for interventions largely stems from the idea that private actors will undersupply these activities. This argument leads to the assumption that subsidizing private sector in some way will help solve the problem. From a Schumpeterian perspective, the policy response can be led by developing national innovation systems that form an environment necessary and sufficient to forge a strong relationship between the key actors involved in creating, diffusing, and utilizing technology and innovation (firms, public labs, government ministries, financial players, and patents and educational systems).

However, in the case of fintech-related innovation, early evidence suggests that the private sector has provided enough innovation, with little need for government subsidy. It is evident that strong economic environments and institutions play important roles in forging links between financial and technology firms. In this regard, it would be useful to ask how finance-related start-ups can be encouraged, and how they can be tied into existing financial system business models. Given that these innovations are highly concentrated in the fintech sector, what sort of institutional support, guidelines on contract enforcement, competition policy, or market structure would be helpful? How do we channel funding for innovation and what is the role of innovation policy?

\section{Issue 3: Strengthening the role of central banks and financial regulators in managing risks and developing the regulatory environment to strike a balance between innovation and financial stability, and to protect consumers.}

As discussed in this paper, there are many macro- and micro-related risks associated with the fintech innovation. At the macro level, technology can be a transmission mechanism for contagion as well as an important source of systemic problems. Financial service providers are increasingly interconnected, which could have significant implication for financial stability. As financial services are increasingly migrated from intermediary-based to network-based providers, it is critical to analyze how such developments affect financial networks and impact interlinked financial systems. Dealing with this may also require regulators to rely less on entity-based regulation.

At the micro level, poor governance or process control can increase the risk of direct disruption to financial services provision. While unbundling of financial services accompanied by the rise of fintech may increase competition and lower fees for consumers, growing fragmentation among service providers and platforms may pose a risk to financial stability. Operational risks are also apparent, such as susceptibility to cyberattacks, reliance on common online platforms, etc. In particular, operation risk can arise from concentration of fintech operations on a small cluster of large players.

An important question is therefore how can innovation be encouraged while addressing these challenges to ensure minimal destruction and greater financial stability? What is the role of central banks and financial regulators in ensuring the policy and regulatory environment that allows technological advancement to thrive but ensures consumer safety and financial stability? How can governments: (i) protect consumers against cybercrimes and fraud, (ii) prevent illegal activities such as money laundering and terrorist financing, (iii) enhance cybersecurity to prevent cyberattacks and hacking, (iv) protect personal data and privacy, and ( $v$ ) balance innovation and financial stability. How do we harmonize these policies and coordinate the regulatory function to maximize the benefits and minimize the costs from technology and innovation? What is the role of RegTech and Sandbox? Does regional cooperation play a role in setting guidelines for regulatory framework or policies? Who takes a lead role in sharing information about fraud and illegal activity? These are important questions. 


\section{Issue 4: Identifying the role of international financial institutions and regional cooperation in addressing challenges and vulnerabilities.}

Improving financial inclusion is very close to the heart of the ADB operations. Over the years, $A D B$ support to financial inclusion has evolved from the launch of the microfinance development strategy in 2000, its inclusion in the Financial Sector Operations Plan, and greater emphasis in the Strategy 2030. Since 2000, ADB has encouraged innovation and best practices that promote greater financial inclusion in the region. In its Strategy 2030, ADB seeks to create an enabling environment for financial inclusion by developing the financial sector through its Private Sector Operations. To tackle short-term financing gaps, ADB will increase its support to banks and nonbank financial institutions to help increase their capacity, quality and reach, particularly to lowincome populations. This will encompass rural finance institutions and MSMEs, and explore new technologies that expand access to financial services. Further, the Financial Sector Operational Plan details the work ADB will do in the sector, recognizing that financial services should go beyond micro loans and include savings, payments and remittances, insurance, and pensions.

Moving forward, a key question is how all stakeholders cooperate and collaborate to support the campaign for inclusive finance through the channels provided by new technologies? What new areas for development finance and investment needs can be supported by application of new financial technologies? What soft and hard infrastructure and policies should Asian policymakers focus on to promote mobile and digital technology? How can they help each other in enhancing data privacy, consumer protection, tracking fraud and other illegal activities that are increasingly more transnational, and in promoting financial literacy? These questions are worthy of further discussion. 


\section{Box 2: ADB Approach to Improve Financial Inclusion}

The Asian Development Bank (ADB) has supported the campaign for inclusive finance by providing loans, credit lines, investments, grants, guarantees, and technical assistance in the following areas: (i) microfinance; (ii) credit cooperatives and credit unions; (iii) agriculture finance and rural microenterprise; (iv) branchless/mobile banking; (v) financial literacy and consumer protection; (vi) remittance management; (vii) savings mobilization; and (viii) rural banks.

Financial inclusion and empowering women are also given greater recognition by ADB in its 2030 Strategy. ${ }^{\text {a }}$ The strategy mandated private sector operations to support financial sector development in developing member countries to achieve greater financial inclusion; gender equality; job creation, and access to affordable housing, insurance, and savings. In tackling short-term financing gaps, ADB will increase its support for banks and nonbank financial institutions to help increase their capacity, quality, and reachparticularly to low-income populations. ADB will also expand the use and reach of its various financial sector programs, such as trade finance, supply chain finance, and microfinance.

\section{ADB supports trade finance to small enterprises and poor households.}

Over the years, emerging economies continue to face the greatest shortfalls in trade finance, partly because of the strategic importance of trade finance in the manufacturing supply chain. To address this gap, ADB has worked with over 240 partner banks to deliver the Trade Finance Program (TFP), which gives guarantees and loans to banks to provide companies with the financial support they need to engage in import and export activities in the region. A substantial portion of TFP's portfolio supports small and medium-sized enterprises (SMEs), and many transactions occur either intraregionally or between ADB's developing member countries. The program supports a wide range of transactions, from commodities and capital goods to medical supplies and consumer goods. Its three main products are Guarantee Products, Funded Products, and Distribution Product (Cofinance). In 2017, ADB supported \$4.48 billion in transactions, $\$ 2.81$ billion in cofinancing, with the assistance reaching 2,822 SMEs. That brought ADB's total TFP portfolio to more than $\$ 30$ billion since 2009. . $^{\circ}$

\section{ADB seeks to promote financial inclusion through fintech.}

ADB has also supported many Fintech related projects such as the following:

- Credit scoring project: The first project is the application of enterprise resource planning solution to allow SMEs to build credit history and gain greater access to finance. We all know that SMEs often have difficulty accessing trade finance. ADB supports KIU—an IT service company-and partner banks in providing SME financing through cloud-based Enterprise Resource Planning, which has enabled credit scoring. As of the end of March 2018, 8,000 SME clients became part of this initiative with loans of up to $\$ 50,000$ per client. ADB provided a $\$ 100$ million SME credit line to a KIU partner bank in Viet Nam. KIU also has partner banks in Cambodia, Myanmar, and Bangladesh.

- $\quad$ FINTECH Challenge Viet Nam (FCV) project: The Mekong Business Initiative partnered with the State Bank of Viet Nam, corporates, and commercial banks to launch the first Fintech Challenge Viet Nam in November 2017. The FCV (worth \$180,000, of which $\$ 160,000$ was contributed by sponsoring banks) aims to encourage the collaboration among banks and fintech providers and promote financial inclusion in Viet Nam. FCV attracted more than 140 global fintech solutions, of which the best 16 were chosen to participate in incubation programs managed by commercial banks. ADB contributed $\$ 150,000$ to organize FCV through technical assistance and will pilot-test the best fintech solutions selected through FCV.

- Change in financial regulations to encourage Laku Pandai in Indonesia. Another project is the Financial Market Development and Inclusion Program - which includes policy-based loans totaling $\$ 800$ million in two subprograms-one supporting the revision of banking regulations to promote branchless banking. Laku Pandai or branchless banking offers banking and services such as savings and loans without any physical branches. It is supported by mobile phones and information technology facilities and could help boost access to banking in rural areas. Presently, the program supports the expansion of branchless banking, which now covers 27 commercial banks and 512 out of 514 provinces.

Aside from projects, ADB support is strengthening supervisory and regulatory frameworks to enable a safer means for innovation that ensures competition, stability, and consumer protection. RegTech and CyberTech need to be addressed in a cohesive way and when new digital products and services are designed. Cybersecurity and data privacy needs be integrated from the outset. These reforms will help consumers have greater confidence and trust in these innovative services. Financial literacy and awareness could also help. Toward this end, for example, ADB developed a reality TV show in Mongolia on financial literacy.

ADB. 2018. Strategy 2030: Achieving a Prosperous, Inclusive, Resilient and Sustainable Asia and the Pacific. Manila.

ADB. 2018. Trade Finance Program Fact Sheet. https://www.adb.org/sites/default/files/publication/29079/trade-finance-program-fact-sheet-2018.pdf

ADB. 2018. “Advancing Financial Inclusion through FinTech in ASEAN.” Presentation. ASEAN Flnance Ministers' and Central Bank Governor's Joint Meeting (AFMGM). 6 April 2018. Singapore. https://www.adb.org/sites/default/files/related/107721/Advancing\%20Financial\%20Inclusion\%20Through\%20FinTech\%20in\%20ASEAN.pdf Source: Asian Development Bank. 


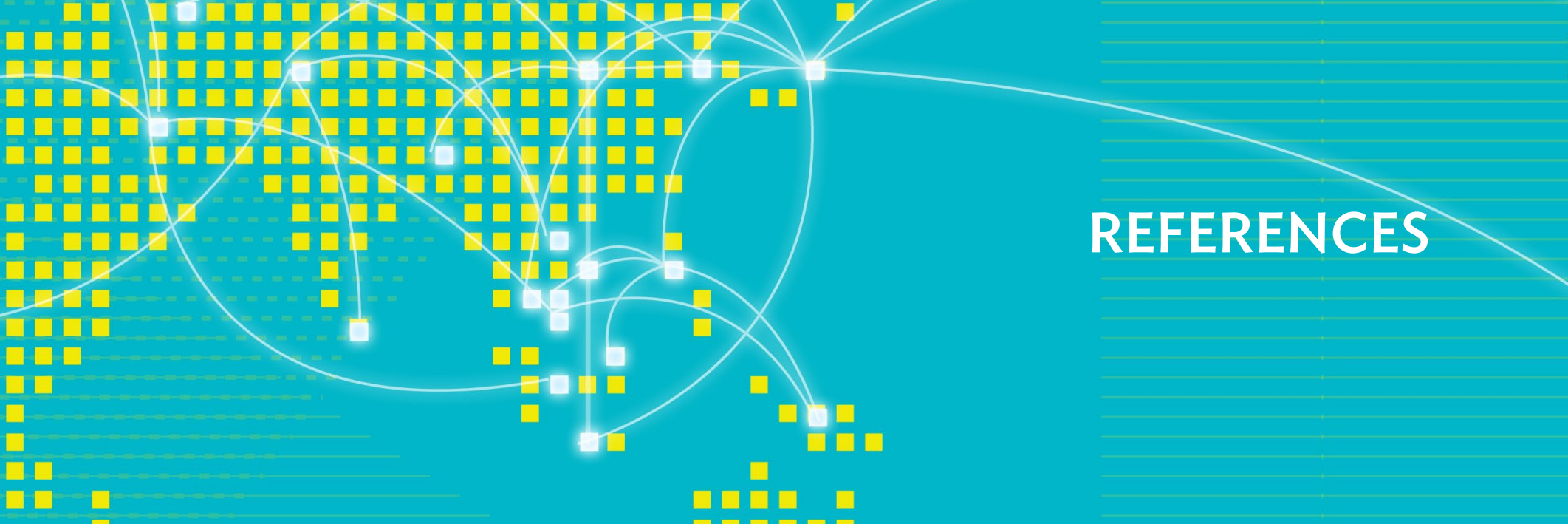

Aghion, Philippe, Nick Bloom, Richard Blundell, Rachel Griffith, and Peter Howitt. 2005. "Competition and Innovation: An Inverted-U Relationship." The Quarterly Journal of Economics 120(2): 701-728.

Asian Development Bank. 2015. Financial Inclusion in Developing Asia. Manila.

Asian Development Bank. 2018. Asian Development Outlook. Manila.

European Parliament. 2018. Competition Issues in the Area of Financial Technology (FinTech). Strasbourg.

Financial Stability Board. 2017. Financial Stability Implications from FinTech. Basel.

International Monetary Fund. 2017. Fintech and Financial Services: Initial Considerations. Washington, DC.

International Monetary Fund. 2018. Financial Inclusion in Asia-Pacific. Washington, DC.

ING. 2016. The Fintech Index: Assessing Digital and Financial Inclusion in Developing and Emerging Countries. Amsterdam.

Jack, William, and Tavneet Suri. 2014. "Risk-sharing and Transactions Costs: Evidence from Kenya's Mobile Money Revolution." American Economic Review 104(1): 183-223.

Mbiti, Isaac, and David N. Weil. 2013. "The Home Economics of E-Money: Velocity, Cash Management, and Discount Rates of M-Pesa Users." American Economic Review 103(3): 369-374.

PERC. 2016. From Competition to Collaboration-Fintech, Big Data, and Traditional Financial Services. PERC: Durham, New Jersey.

PWC. 2017. Fintech Trends Report India 2017.

World Bank. 2008. Finance for All? Washington, DC.

World Economic Forum. 2015. The Future of Financial Services. Geneva.

World Economic Forum. 2016. A Blueprint for Digital Identity. Geneva. 




\section{Harnessing Technology for More Inclusive and Sustainable Finance in Asia and the Pacific}

Asia and the Pacific continues to embrace financial technology advances that are reshaping the traditional banking and financial services industry. This is being done through the digitalization, decentralization, and disintermediation of economic transactions. This report tracks the progress of financial innovation in the region, and discusses its implications for financial inclusion and stability as well as its challenges. It also identifies key policy issues for central banks, financial regulators, and international financial institutions.

\section{About the Asian Development Bank}

ADB is committed to achieving a prosperous, inclusive, resilient, and sustainable Asia and the Pacific, while sustaining its efforts to eradicate extreme poverty. Established in 1966, it is owned by 67 members48 from the region. Its main instruments for helping its developing member countries are policy dialogue, loans, equity investments, guarantees, grants, and technical assistance. 